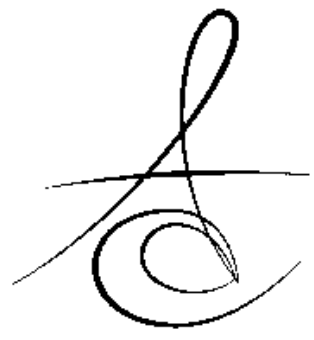

\title{
THE EFFECT OF BISPHOSPHONATES AND LOW-DOSE DOXCYCLINE THERAPY IN DIABETICS WITH PERIODONTITIS: A REVIEW
}

\author{
DÜŞÜK-DOZ DOKSİSIKKLIN VE BİFOSFONAT TEDAVİSINNİN \\ PERİODONTİTISLI DİYABET HASTALARINDAKİ ETKİSİ: DERLEME
}

\author{
Yrd. Doç. Dr. Şeyma BOZKURT DOĞAN* \\ Yrd. Doç. Dr. Figen ÖNGÖZ DEDE**
}

Makale Kodu/Article code: 2572

Makale Gönderilme tarihi: 28.01 .2016

Kabul Tarihi: 16.03.2016

\section{ABSTRACT}

Diabetes mellitus and periodontal disease are chronic diseases affecting a large number of populations worldwide. The major component of soft and hard tissue destruction associated with periodontal disease is the result of activation of the host immunoinflammatory response to the oral pathogens. Diabetes mellitus alters bacteria-host interactions by prolonging the inflammatory response and dysregulating cytokine production, and is among the primary risk factors for periodontal disease. Alveolar bone loss is one of the main outcomes of periodontitis. One of the important long-term complications associated with diabetes mellitus is changed bone metabolism. Recently, the therapeutic strategies for the treatment of periodontal disease have been directed towards to host modulation therapy. In this review, we will evaluate the effects of bisphosphonates and low dose doxcycline drugs as host modulation agents in the treatment of periodontal disease and in diabetics with periodontal disease.

Keywords: Periodontitis, diabetes mellitus, bisphosphonate, doxycycline, alveolar bone loss

\section{öz}

Diabetes mellitus ve periodontal hastalıklar, dünya popülasyonunun geniş bir kitlesini etkileyen kronik hastalıklardır. Periodontal hastalıklar ile ilişkili sert ve yumuşak doku yıkımı, oral patojenlere karşı konak immuno-inflamatuvar cevabın aktivasyonu sonucu meydana gelmektedir. Diabetes mellitus, sitokin üretiminin düzenlenmesini bozarak ve inflamatuvar cevabı uzatarak bakteri-konak etkileşimini değiştirmektedir ve periodontal hastalıklar için başlıca risk faktörleri arasındadır. Periodontitisin temel klinik özelliklerinden biri alveoler kemik kaybıdır. Diabetes mellitus ile ilişkili önemli uzun-süreli komplikasyonlarından biri, kemik metabolizmasındaki değişimdir. Son zamanlarda periodontal hastalı̆ı̆ tedavisi için uygulanan terapötik stratejiler konak modülasyon tedavisine doğru yönelmiştir. Bu derlemede, periodontal hastalıklı diyabet hastalarında ve periodontal hastalığın tedavisinde konak modülasyon ajanları olarak kullanılan bifosfonatlar ve düşük-doz doksisiklin ilaçlarının etkilerini değerlendireceğiz.

Anahtar Kelimeler: Periodontit, diabetes mellitus, bifosfonat, doksisiklin, alveolar kemik kaybı

\section{INRODUCTION}

Periodontal disease is a chronic inflammatory condition characterized by loss of connective tissue attachment to the teeth and resorption of the alveolar bone due to the inflammatory processes. ${ }^{1,2}$ Previous reports have indicated that periodontitis may have profound effects on systemic health., 4 Periodontitis has been referred to as the sixth complication of diabetes after microangiopathy including retinopathy, nephropathy, macrovascular disease, and delayed wound healing. ${ }^{5}$ Many studies have long recognized that disease is common among diabetic patients and becomes worse with the progression of diabetes. ${ }^{6,7}$ Several mechanisms have been reported to explain the greater incidence and severity of periodontal disease in patients with diabetes mellitus (DM). These include polymorphonuclear leukocyte (PMN) dysfunction, vascular changes, altered collagen and glycosaminoglycan synthesis, deregulated cytokine production, and the formation of advanced glycation end products (AGEs). Additionally, DM alters bacteria-host

\footnotetext{
*Ankara Yıldırım Beyazıt Üniversitesi Diş Hekimliği Fakültesi Periodontoloji AD

** Ordu Üniversitesi Diş Hekimliği Fakültesi Periodontoloji AD
} 
interactions by prolonging the inflammatory response and dysregulating cytokine production. ${ }^{6,8}$

Although periodontal diseases are initiated by bacteria that colonize the tooth surface and gingival sulcus, the host response, which is primarily responsible for the destruction of connective tissue constituents and bone, has led to host-modulation therapies in the management of infectious diseases. ${ }^{9}$, 10 Host modulatory therapy (HMT) is a treatment concept that aims to decrease tissue destruction and stabilize or regenerate the periodontium by modifying or downregulating destructive aspects of the host response and upregulating protective or regenerative responses. ${ }^{7}$ One group of hostmodulation agents is the bisphosphonates (BPs), the carbon-substituted pyrophosphate analogs that are potent inhibitors of bone resorption and have been effectively used to control osteolysis or reduce bone loss in Paget disease, metastatic bone disease, hypercalcemia of malignancy, and osteoporosis. ${ }^{711,12}$ Additionally, recent data indicate that there is a potential role for BPs in the management of periodontitis. ${ }^{7,10,13}$ Alt- hough, various side effects were reported, with their potent therapeutic effects and improvements in patients quality of life, their use has become widespread. The other group of host modulation agent is non-antimicrobial formulations of tetracycline (low-dose doxycycline [LDD]), contributes to decreased connective tissue breakdown by downregulating the expression of proinflammatory mediators and cytokines and increasing collagen production, osteoblast activity, and bone formation. LDD therapy reduces host-derived collagenase activity in gingival tissue with

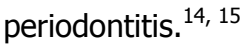

Recently, there are researches about the use of BPs, LDD and the use of combination of these agents in diabetics with periodontitis. The goals of this review are to evalute the putative mechanism of these drugs and potential side effects in oral tissues, and to discuss their potential use in periodontitis patients with and without diabetes mellitus.

\section{BISPHOSPHONATE STRUCTURE AND} MECHANISMS OF ACTION

BPs are analogs of pyrophosphate with oxygen replaced by carbon in the pyrophosphate bond to form a phosphate-carbon-phosphate (P-C-P) structural backbone with two side chains, $R_{1}$ and $R_{2}{ }^{16,} 17$ The binding to bone mineral is enhanced by including a hydroxyl group at R1. The R2 structure and 3 dimensional configuration determine the cellular effects of BPs, and their relative efficacies as inhibitors of bone resorption. ${ }^{18}$ The two side chains dictate the anti-resorptive potency of an individual BP and determine the extent of BP binding to hydroxyapatite (HA). BPs inhibit bone resorption by binding to HA, inhibiting formation of crystals and preventing or slowing their dissolution. Because of the high affinity of BPs for HA bone mineral, these drugs are targeted to areas of bone turnover and are especially concentrated in sites of osteoclastic bone resorption. ${ }^{19}$ BPs can affect osteoclast-mediated bone resorption in a variety of ways, including osteoclast recruitment and differentiation, and may induce apoptosis and direct inhibition of osteoblast-mediated cytokine production. ${ }^{7}$

BPs can be seperated into two general classes according to their chemical structure and molecular mechanism of action. Alkyl side chains, first generation non-nirogen containing BPs (e.g. etidronate, clodronate), had minimally modified side chains of the pyrophosphage molecule or contained a chlorphenyl group. These BPs can accumulate intracellularly in osteoclasts as non-hydrolysable analogues of adenosine triphosphate (ATP) and induce apoptosis. Their cumulative cell cytotoxicity effectively inhibits bone resorption by causing osteoclast apoptosis. With the addition of a nitrogen group in the side chain, second generation BPs (e.g., alendronate, pamidronate) potency increased by ten- to a hundred-fold. Third generation BPs have cyclic side chains (e.g., risedronate, zoledronate) and their potency increased by 10,000 times when a heterocyclic ring containing nitrogen was inserted into the drug molecule. ${ }^{18,} 20$ The nitrogen-containing BPs (N-BP) inhibit the mevalonate pathway of cholesterol synthesis via inhibition of the enzyme farnesyl diphosphate synthase (FPP) and blocking prenylation of small GTPases leading to interruption of osteoclast function. The final outcome is a reduction in osteoclast activity and increased apoptosis. ${ }^{21}$ Although their primary action may be an inhibitory effect on osteoclasts, increasing attention is being given to other effector cells that may be influenced by BPs. In recent years, it has been hypothesized that a further target of BPs may be osteoblasts, which subsequently influence osteoclasts. ${ }^{22}$ Therefore, BPs also inhibit osteoclastic activity indirectly through bone marrow stromal cells and osteoblasts. Osteoblasts enhance osteoclast recruitment and activitation by interaction of osteoblasts cell 
surface receptor activator of NFKB ligand' (RANKL) with RANK on hematopoietic osteoclast precursor cells. Osteoblasts also secrete osteoprotegerin (OPG), asoluble decoy receptor that competes with RANKL for RANK to inhibit osteoclast recruitment and control osteoclast-osteoblast balance. BPs inhibit RANKL expression and enhance OPG production by bone marrow stromal cells. These synergistic actions lead to supression of osteoclast recruitment and reduction of bone resorption. ${ }^{6}$

Each bisphosphonate has its own activity profile. Several modes of action have been reported, including inhibition of the development of osteoclasts, induction of osteoclast apoptosis, reduction of activity, and stimulation of the production of an osteoclast inhibitory factor. ${ }^{23-26}$ However, the exact mechanism of actions of the drug in periodontal disease is not known.

USE OF BISPHOSPHONATES IN DIAGNOSIS AND MANAGEMENT OF PERIODONTITIS

Several BPs have been tested for clinical use, but it is difficult to directly compare them because each of them has different physicochemical and biological properties. There are nine BPs approved for clinical use by the FDA (Alendronate sodium, Alendronate sodium plus vitamin D, Etidronate disodium, Ibandronate sodium, Pamidronate sodium, Risedronate sodium, Risedronate sodium plus calcium carbonate, Tiludronate disodium, Zoledronate acid) BPs can be orally or intravenously administered ${ }^{16}$. Seven of the nine BPs have been approved for oral administration while pamidronate and zolendroic acid are given intravenously. ${ }^{16}$ The bioavailability of oral administration can be lower than $1 \%$, on the other hand, about $50 \%$ of dosage drug binds to bone surfaces in the intravenous administration. ${ }^{27}$

Research studies have evaluated BPs application using different experimental models in dentistry, i.e., implantology 28,29 , orthodontics ${ }^{30}$ and they have been shown to prevent dental calculus formation ${ }^{31}$ and are benefical in modulating host responses in the management of periodontal diseases. ${ }^{26}$ Additionally, there are researches suggesting that radiolabeled BP can be used to detect periodontal bone loss in animal models $^{32,33}$ and human periodontitis. ${ }^{34}$ However, the diagnostic use of BFs has not come into routine use for reasons related to cost, accesssibility, and full-body irridation.
The BPs and their implications to dentistry have been extensively reviewed. To this point, we would like to draw attention to the potential use of BPs in the management of periodontal disease-associted bone loss. BPs have been used as inhibitors of bone resorptionn and matrix-metalloproteinases (MMPs) in the treatment of periodontitis. ${ }^{14,35}$ Evidence suggest that BPs depending on the their chemical characterics and using dosage have different effects on the alveolar bone. ${ }^{22}$ There is a difficulty in comparing data from various publications because they all included different families and doses of administrated BPs. One of the most common investigated BP is alendronate, an aminobisphosphonate, proved to be effective as adjunctive treatment in both patients with type $2 \mathrm{DM}$ and post-menopausal women with little or no sideeffects. $^{25,} 36$ Previous studies have demonstrated the effects of systemic alendronate in human ${ }^{37,38}$ and animal models ${ }^{39}, 40$ in decreasing loss and increasing density of alveolar bone. de Almeida et al. ${ }^{41}$ concluded that topical use of sodium alendronate as an adjuvant to scaling and root planing (SRP) shown to be effective in treatment of experimental periodontitis. Goes et al. $^{42}$ found that alendronate prevented reduction of bone-specific alkaline phosphatase serum levels (BALP), alveolar bone loss and reduced inflammatory infiltrate, without causing systemic alterations. Two studies ${ }^{10,43}$ show that local delivery of $1 \%$ alendronate gel stimulated a significant increase in probing depth reduction, clinical attachment gain, and improved bone fill compared to a placebo gel as an adjunct to SRP in the treatment of chronic and agrressive periodontitis.

Disodium chlodronate, a BP that is potent inhibitor of osteoclast-mediated bone resorption, has been shown to have anti-inflammatory properties. ${ }^{44}$ Alencar et al. ${ }^{44}$ studied the effect of chlodronate in an experimental periodontitis model focusing on antiinflammatory and anti-resorptive properties and they found that both prophylactic and curative chlodronate treatment decreased alveolar bone loss, as compared to non-treated group. Mitsuta et al. ${ }^{45}$ showed that topical administration of chlodronate significantly prevented alveolar bone loss. In another study ${ }^{9}$ a combination of a chemically modified doxycycline and chlodronate were used in the experimental periodontitis model and they found that combined therapy significantly reduced alveolar bone loss and tooth loss compared to monotherapies. Additionally, pamidro- 
nate, ${ }^{46}$ etidronate, ${ }^{47,48}$ risedronate, ${ }^{26,49,50}$ olpandronate $^{24}$ neridronate ${ }^{35}$ tiludronic acid ${ }^{51}$ were investigated in the periodontitis studies. Studies mentioned above almost have shown an obvious benefit of BPs as adjuvants to the mechanical periodontal treatment that resulted in reduced alveolar bone resorption. On the other hand, some researches showed an increased periodontal destruction and inflammation when high doses of BPs were administrated. ${ }^{52}$ It speculated that high doses of BPs stimulate the local release of proinflammatory cytokines, such as interleukin -1 beta ( $\mathrm{IL}-1 \beta)$ and IL- 6 in the periodontal tissues and hence prevent the periodontal wound-healing process. ${ }^{53,54}$

EFFECTS OF BISPHOSPHONATES ON BONE LOSS IN DIABETES MELLITUS

DM has significant impact on tissues throught the body, including oral cavity. Research indicates that diabetes, especially when poorly controlled, increases risk of periodontitis. ${ }^{55}$ Diabetes is also associated with microvascular ischemia of bone, ${ }^{56}$ bone turnover and remodeling decrease, ${ }^{57}$ and induction of osteoblast and osteocyte apoptosis. ${ }^{58}$ Diabetes potentiates the severity of periodontitis and accelerates bone resorption. Diabetes affects osteoclast and osteoblasts in the periodontium in different ways, such as by increasing the expression of inflammatory mediators and RANKL/ OPG ratios and by enhancing the levels of AGEs and reactive oxygen species (ROS). ${ }^{59}$ Osteocalcin (OC) is an osteoblast lineage-derived secreted protein, forming the $1 \%-2 \%$ of the bone matrix. ${ }^{60}$ The serum level of OC is considered as a marker of bone formation. ${ }^{61}$ Serum levels of $\mathrm{OC}$ in periodontitis patients were reported to be lower in periodontitis patients compared to healthy subjects suggesting lower osteoblastic activity and bone formation ability. ${ }^{62}$ Higher level of un(der)carboxylated OC (ucOC), a protein produced by osteoblasts and metabolized under the influence of osteoclasts during bone remodeling, was found to increase insulin secretion and sensitivity in mice. ${ }^{63} \mathrm{BPs}$, potent inhibitors of osteoclastic activity, do suppress bone turnover and decrease systemic uOC levels. ${ }^{64}$ Therefore, BP therapies, which reduce ucOC levels, may increase the risk of insulin resistance and diabetes. Alendronate has been shown to reduce ucOC by $56 \% .{ }^{65}$ In rodent models study, ${ }^{66}$ antiresorptive therapy with reductions in ucOC and OC could lead to insulin resistance, lower insulin secretion, weight gain and an increased risk of diabetes. On the contrary, some studies ${ }^{64,} 67$ found that antiresorptive therapy does not have a clinically important effect on fasting glucose, weight or diabetes risk. Result of observational studies of the longitudinal effects of $\mathrm{OC}$ and ucOC levels on glucose metabolism have been inconsistent. ${ }^{68-70} \mathrm{OC}$ levels are lower in those with diabetes, but this might be due to negative effects of diabetes on bone formation. ${ }^{71}$

There are few studies about the effect of BPs in the treatment of diabetic patients with periodontitis. Rocha et al. ${ }^{36}$ reported significant improvement in the healing response compared to the placebo group with the use of systemic alendronate for 6 months in the treatment of patients with chronic periodontitis and type 2 DM. The other study ${ }^{72}$ showed that local delivery of $1 \%$ ALN into periodontal pockets resulted in a significant increase in the probing depth reduction, clinical attachment gain, and improved bone fill compared to placebo gel as an adjunct to SRP in patients with type $2 \mathrm{DM}$ and chronic periodontitis. Özdemir et al. ${ }^{7}$ investigated the effects of LDD and bisphosphonate clodronate on alveolar bone loss and gingival levels of MMP-9 and IL-1 $\beta$ in experimental periodontitis with diabetes. They found that use of mono and combined clodronate and LDD administrations may significantly reduce levels of MMP-9 and IL-1 $\beta$ expression. However, drug administration did not affect alveolar bone levels.

\section{BISPHOSPHONATE-RELATED OSTEONECROSIS OF THE JAW}

Osteonecrosis is a term commonly used to describe death of bone cells and osteonecrosis of the jaw (ONJ) is defined as exposed necrotic bone in maxillofacial region which fails to heal after 6 to 8 weeks in patients with no history of craniofacial radiation. ${ }^{73}$ Painful exposure of bone in the mandibula and maxilla of patients receiving the BPs pamidronate and zolendronate was first reported by Marx in 2003. ${ }^{74}$ The BPs most frequently associated with bisphosphonate-related osteonecrosis of the jaw (BRONJ) are the aminobisphosphonates, which include alendronate, pamidronate, and zoledronic acid, and intravenous administration has been associated with the majority of cases. ${ }^{75,76}$ Although alendronate is an aminobisphosphonate, it is associated with a lower prevalence of BRONJ when compared to zoledronic acid and pamidronate. ${ }^{77}$ This is especially because of its oral administration route, which results in lower absorption and lower cumulative dose. The risk of BRONJ development for patients on intravenous BPs is 
estimated at between $1 \%$ and $11 \%$, and it increases after longer treatment time. BRONJ in patients taking oral BPs for osteoporosis is rare, estimated at $0.001 \%$ to $0.1 \%{ }^{78}$

The pathogenesis of BRONJ is not completely defined, but currently, two main hypothesis explain the mechanism for the complication of BP therapy. The first explains the pathology in terms of the osteoclastic-inhibiting effect of this class of drug on the cessation of bone remodelling and bone turnover. The second theory states that the inhibition of neoangiogenesis by BPs lead to loss of blood vessels in the jaws and avascular necrosis. ${ }^{17}$ Also altered functioning of oral mucosal cells, microbial flora, and a proinflammatory effect may cause to BRONJ after administration of BPs. There are several $\operatorname{cases}^{79,80}$ of BP-induced stomatitis, and the oral mucosa is seperated from the bone of the jaw.

There are several putative factors that may place the patient at risk for BRONJ. These factors include pharmacokinetic and pharmacodynamic factors associated with BPs, comorbid medical conditions (e.g., diabetes, coagulopathy, blood dyscrasias, malignancy), dental factors (e.g., dentoalveolar surgery, trauma, periodontal disease, poor oral hygiene), age, environmental factors (e.g., alcohol and tobacco use), concomitant medications (e.g., glucocorticoids, estrogens), and skeletal factors (e.g., low bone mineral density). ${ }^{20,81}$ Periodontitis occurs in $71 \%$ to $84 \%$ of ONJ cases, suggesting it may be a risk factor. ${ }^{82,} 83$ In the great majority of cases, BRONJ occurs after extraction of teeth deemed unrestorable owing to the severity of dental disease or around teeth with active periodontal or periapical disease. ${ }^{76}$, 78,82 In a series of 152 BRONJ cases, for 85 patients $(56 \%)$, the initiating event for ONJ was either extraction owing to periodontitis, extraction owing to failing root canal, uncontrolled periodontitis, periodontal surgery, or apicoectomy. ${ }^{84}$ Nitrogenous BPs (NBPs) appear to have a proinflammatory effect, having been shown in vitro to enhance lipopolysaccharide-induced IL-1 $\beta$, IL-6, and tumor necrosis factor- $\beta$ expression. ${ }^{85-}$ 87 These findings suggest that NBPs may exert effects that favor an inflammatory environment, which may have implications for the progression of periodontitis and ONJ risk.

DM is one of the systemic risk factors contributing in the development of BRONJ. ${ }^{88}$ The microvascular changes in diabetes, combined with the effects exerted by BPs, could favor the development of alveolar bone necrosis. The presence of diabetes or impaired fasting glucose apparently correlates with a higher prevalence of microvascular disease in diabetic BRONJ patients compared with diabetic controls. ${ }^{89}$ Berti-Couto et al. ${ }^{90}$ investigated the influence of diabetes and corticotherapy on the development of osteonecrosis of the jaws associated with sodium alendronate. They showed that not corticotherapy but diabetes was associated with jaw osteonecrosis in rats undergoing alendronate therapy and subjected to tooth extractions. Watters et al. ${ }^{91}$ reported a significant correlation between poor BRONJ prognosis and the diagnosis of diabetes, A case-control study reported a higher rate of BRONJ in DM patients (17\%) than in individuals without $\operatorname{DM}(11 \%) .^{92}$ Delayed wound healing, altered microvascular function, and impaired bone metabolism are pathways that may predispose individuals with diabetes to develop BRONJ. Poor glycemic control is a risk factor for increased severity of dental disease, ${ }^{93}$ and this may increase the risk for BRONJ. The likelihood of a concomitant diagnosis of BRONJ with DM is supported by the immunosuppression and delayed wound healing that is known to occur in patients with poorly controlled DM after dental surgery or trauma. ${ }^{94}$

\section{DOXYCYCLINES}

The tetracycline (TC) family consists of broad spectrum bacteriostatic antibiotics that act by inhibiting bacterial protein synthesis. ${ }^{95}$ TCs have nonantimicrobial properties that include the inhibition of neutrophil and osteoblasts collagenases, as well as the inhibition of osteoclast function. ${ }^{96}$ TCs have been found to inhibit collagenases and several other MMPs by a mechanism independent of their antimicrobial activity. ${ }^{7}$ TCs with anticollagenolytic properties have a positive effect on the healing of hard tissues. ${ }^{97}$ It also tends to indicate a bone forming activity. ${ }^{98}$ Although several mechanisms of TCs have been proposed to explain the benefit effects, which include the enhancing of bone formation, decreasing of connective tissue breakdown and diminishing of bone resorption, the most widely investigation is related to the ability of these agents to inhibit the activity of MMPs. ${ }^{98}$ TCs have also been investigated for its ability to prevent the systemic complications of diabetes. ${ }^{96}$

Doxycycline, a broad-spectrum antimicrobial agent, is a tetracycline derivative which has been 
widely used as an adjunct in the treatment of periodontal disease. ${ }^{99-102}$ Doxycycline was found to be a more effective inhibitor of collagenases than the other TC analogs. ${ }^{7,100,103}$ Doxycycline contributes to decreasing of connective tissue breakdown by downregulating the expression of proinflammatory mediators, cytokines, increasing collagen production, osteoblast activity and bone formation. ${ }^{104}$ It offers advantages over the two other drugs as its absorption from the gastro-intestinal tract is not altered by calcium, metal ions or anti-acids. It has more potent compliance and is associated with less photo and renal toxicity. ${ }^{97,} 105$ It also increases protein synthesis and secretion in periodontal ligament fibroblasts, facilitates osseous healing in advanced periodontal furcation defects, inhibits tissue collagenases, and prevents root resorption and alveolar bone loss after periodontal surgery. ${ }^{97}$

The properties of doxycycline seem to be useful in periodontal therapy because of its antibacterial, anti-collagenolytic, anti-inflammatory effects, and fibroblast-stimulating activities. ${ }^{106,} 107$ Doxycycline was able to inhibit in vitro osteoclastogenesis and cause apoptosis of mature osteoclasts due to bone resorption. These effects extend beyond the mere inhibition of MMP. ${ }^{108,109}$ Studies stated that improvements in clinical outcomes occurred in the normal periodontal flora without detrimental shifts, at the acquisition of doxycycline resistance and at the multiantibiotic resistance. ${ }^{99,110}$

\section{USE OF LOW-DOSE DOXYCYCLINE IN THE TREATMENT OF PERIODONTAL DISEASE}

Subantimicrobial dose of doxycycline is a novel 'low-dose' formulation (20 mg b.i.d., compared to 'regular or antibiotic-dose' $100 \mathrm{mg}$ q.d. or b.i.d.) of TC. $^{111}$ LDD (Periostat ${ }^{\mathrm{TM}}$, CollaGenex Pharmaceuticals, Inc. Newtown, PA: now Galderma R\&D, Fort Worth, TX) has been approved by the United States Food and Drug Administration (FDA) and other national regulatory agencies in Canada and Europe. ${ }^{15}$ This low dose, which is antimicrobially ineffective, was found to be safe, effective and well-tolerated. ${ }^{99}, 112,100,101$ LDD has been approved as a host response modifier for the management of periodontal disease. It was designed to: (a) suppress host-derived MMPs in the periodontal lesion therapy and inhibiting bone resorption, and (b) prevent complications of 'regular-dose' TC (e.g. doxycycline) administration, such as gastrointestinal disturbance, increased photosensitivity and the emergence of antibiotic-resistant microorganisms. ${ }^{15}$, $111,113,114$ The positive effects of LDD were observed in clinical trials in patients with chronic periodontitis. ${ }^{98}$ Additionally, LDD formulations have demonstrated evidence of safety and efficacy in humans with a variety of other diseases and conditions as well, including pemphigoid, rheumatoid arthritis (RA), postmenopausal osteopenia, type 2 DM, cardiovascular diseases and a rare and fatal lung disease, lymphangioleiomyomatosis. ${ }^{112}$

LDD has been notified as an adjunct to periodontal SRP for the treatment of adult periodontitis. ${ }^{112}$, 115 Several studies have shown that use of LDD as adjunctive therapy to SRP could provide additional benefits in the management of chronic periodontitis compared to non-surgical periodontal treatment alone. ${ }^{99,101,110,112,116}$ Golub et al. ${ }^{99}$ determined that LDD regimen administered to patients with adult periodontitis can reduce pathologic elevations in gingival crevicular fluid (GCF) collagenase activity and improve attachment level measurements. Mavragani et al. ${ }^{100}$ demonstrated that systemic administration of LDD inhibited root resorption, alveolar bone loss, increased the alveolar bone mass and decreased number of osteoclast in the rat with experimental orthodontic tooth movement. Another experimental study showed that percentage of new bone formation enhanced with the use of LDD after tooth extraction. ${ }^{117}$ Additionally, Yağan et al. ${ }^{15}$ found that alveolar bone loss in the rats with experimental periodontitis treated with LDD was lower than control rats. The reduction of alveolar bone loss may be explained by the use of LDD, since it possess to a potent inhibitor of osteoclastic function. ${ }^{105}$

\section{THE USE OF DOXYCYCLINE IN DIABETES MELLITUS WITH PERIODONTAL DISEASE}

The use of doxycyclines as adjunctive therapy to SRP may help not only improving the periodontal status but also reducing the risks for other significant medical conditions including diabetes, heart attack, stroke and other cardiovascular diseases. ${ }^{95,} 103$ The studies on type I and type II diabetic rats demonstrated that the non-antibiotic properties of TCS were effective in reducing the severity of a variety of abnormalities including (but not limited to) those in collagen structure, turnover and in bone remodeling (both locally in the oral tissues and systemically) that contribute to the pathogenesis of diabetic complications, such as unusually severe periodontitis. ${ }^{118,} 119$ Singh et al. ${ }^{120}$ study indicated that protein synthesis 
and secretion was increased in the periodontal ligament fibroblasts of diabetic rats by administration of TC. Thus, the use of TCs and their derivatives in individuals with diabetes could be useful for the management of periodontal disease. Moreover, administration of doxycycline additional to periodontal therapy has the potential to alter diabetes metabolic control. ${ }^{107,121,122}$ Also it has stated that doxycycline inhibits non-enzymatic glycation of extracellular proteins, and it may have a similar effect on the glycation of hemoglobin. ${ }^{123}$ Several studies suggest that the administration of systemic doxycycline can result in improvement of metabolic control especially in poorly controlled type 2 DM periodontitis patients. ${ }^{136,138,123,124}$ It is interesting that in short-term (3 months) adding doxycycline to non-surgical periodontal therapy in uncontrolled diabetics did benefit in glycemic control. ${ }^{121}$ The use of adjunctive systemic doxycycline to SRP therapy improved the periodontal parameters in uncontrolled type 2 DM patients compared to group SRP alone. ${ }^{120,121}$ On the contrary, some of the studies did not significantly improve the results. ${ }^{122,123,125}$ Moreover, the use of systemic doxycycline as adjunctive therapy in Type 1 DM patients with periodontitis did not improve levels of glycemic control. ${ }^{107,126}$

Deo et al. ${ }^{127}$ evaluated the clinical efficacy of LDD together with SRP in DM patients with CP. They concluded that combined SRP and LDD therapy was more effective than SRP alone in terms of clinical attachment gain and probing depth reduction in DM patients with severe periodontal disease. Engebretson and Hey-Hadavi ${ }^{128}$ analyzed the metabolic control efficacy of SRP combined with LDD therapy (20mg bid for three months) and SRP combined with systemic doxycycline therapy (100 mg each day for 14 days) in type 2 DM patients with periodontal disease. They found that mean HbA1c level after 3-month reduced significantly in SRP+LDD therapy group, while systemically doxycycline + SRP therapy group was not effective in the levels of glycemic control. On the contrary, Gilowski et al. ${ }^{129}$ did not found improvement in the glycemic level of patients with T2DM in the SRP+LDD therapy group. It has reported that LDD intake in patients with type 2 diabetes for three months appeared to be well-tolerated and did not cause serious adverse effects. ${ }^{128,129}$

\section{EFFECT OF LOW-DOSE DOXYCYCLINE THERAPY ON ALVEOLAR BONE LOSS IN DIABETES MELLITUS}

A recent review stated that tetracycline reduced the severity of both alveolar bone loss and systemic bone loss or osteoporosis in patients with type 2DM. ${ }^{112}$ Tetracycline administration normalizes the structure and acid phosphatase activity of osteoclasts $^{130}$ and restores osteoblast structure and function in the diabetic rats. ${ }^{131}$ Golub et al. ${ }^{111}$ determined that doxycycline prevented the development of the bone deficiency disease without affecting the severity of hyperglycemia in the rat with diabetesinduced osteopenia. On the other hand, doxycycline treatment did not prevent or alleviate the deleterious changes in trabecular microarchitecture, cortical structure, and biomechanical properties of bone induced by chronic diabetes. ${ }^{132}$

Alkan et al. ${ }^{97}$ examined the effects of systemic doxycycline administration on the healing of tibial bone defects in experimentally induced diabetic rats. They concluded that doxycycline administration did not significantly alter the amount of bone formation during the healing of bone defects in diabetic rats. Also, they determined that histologic observation of a few samples revealed a smaller number of osteoclasts in the doxycycline-treated diabetic and control rats than in non-treated doxycyline groups. Additionally, Kopman et al. ${ }^{96}$ showed that systemic administration of doxycycline did not enhance osseointegration in the diabetic animals treated with doxycycline compared to diabetic control group. Moreover, Özdemir et al. ${ }^{7}$ found that LDD administration did not affect alveolar bone levels in the diabetic rat with ligature-induced periodontitis. On the contrary, Tella et al. ${ }^{105}$ analyzed the effects of LDD on periodontal defects by experimentally inducing on the lower anterior teeth using an orthodontic elastic ligature in diabetic rats. They found that there was a significant increase of the number of osteoblasts and decreased number of osteoclasts and inflammatory cell infiltration in the doxycycline treated group when compared to control group. LDD was also effective in decreasing bone resorping activity in the diabetic rats. ${ }^{105}$ It asserted that the results of studies can be effected some factor, such as the number of rats in the study, excessive trauma caused during defect preparation, nonoptimum defect size, and variable glucose levels in the rats. 


\section{COMBINED THERAPY OF BISPHOSPHONATE AND DOXCYCLINE ON ALVEOLAR BONE LOSS}

To date, the potential effects of doxycycline and BP administration on alveolar bone loss have been evaluated in models of experimental periodontitis, mostly by morphometric and radiographic methods. However, our literature research revealed that there are the limited number studies about the effect of combined BP and doxcycline therapy in the treatment of periodontal disease.

Llavaneras et al. $^{9}$ investigated the effect of combination therapy using chemically modified doxycycline and BP (clodronate) in an endotoxininduced non-diabetic rat periodontitis model. They concluded that combined therapy leads to reduction of periodontal soft and hard tissue destruction and is associated with inhibition and downregulation of MMPs. Yaffe et al. ${ }^{133}$ explored the local delivery of doxycycline, alendronate, TC, and combined efficacy of these drugs on alveolar bone loss. Their results demonstrated that alendronate was effective and doxycycline alone was the most effective, but TC alone was not effective in reducing bone loss. Combination of alendronate and TC was synergistically effective and combined treatment of alendronate+ doxycycline showed no additive effect. Buduneli et al. ${ }^{134}$ evaluated the combined effects of LDD and alendronate on the gingival tissue and alveolar bone loss. They found that alveolar bone loss in the alendronate and combination groups was less than doxcycline and control groups, but the differences were not statistically significant. Similiarly, they showed in their studies that alendronate either alone or in combination with doxycycline provided slight inhibition on lipopolysaccharide (LPS)-induced alveolar bone resorption. ${ }^{14,61}$ However, in one of these studies significantly increased serum OC level was observed in the combined drug treatment group. ${ }^{61}$ Therefore, they suggested that combined administration of alendronate and doxycycline might increase bone remodeling and thereby inhibit the progression of alveolar bone resorption in rats. Only one study evaluated the effect of mono and combined BP clodronate and LDD therapies on the alveolar bone loss in rats with diabetes. They determined that there were no statistically significant differences in bone levels among LDD, BP, and a combination therapy. ${ }^{7}$

\section{CONCLUSIONS}

Alveolar bone resorption is the principal sequela and the cause of tooth loss in patients afflicted by periodontal disease. The use of bonesparing drugs that inhibit alveolar bone resorption is a treatment field in host-modulation therapy. Based on the present knowledge of BPs, the use of BPs in periodontal research shows a promising method of managing periodontal diseases by modifying the host response. Published studies tend to demonstrate that BPs prevent or at least reduce the alveolar bone loss in comparison with control subjects. It is also conceivable that in the future, such drugs will not only be used to prevent bone loss observed in periodontal diseases, but also to possibly stimulate new bone formation. On the other hand, BRONJ is the most significant side effects of BPs on oral tissues and DM is one of the systemic risk factors contributing in the development of BRONJ and periodontitis. A simple way to avoid the side effects could be the topical use of BPs with a drug-delivery system. However, at this point, there is a lack of data determining the optimal prescription concentration and formulation of BPs in the treatment of periodontal disease and DM. The potential biases and other explanations for these findings must be investigated and evidence of a potential association between BPs and risk of DM would also provide a confirmation of alveolar bone loss.

As a result of several decades of extensive clinical trials, which have been described in many reviews, the clinically significant benefits of LDD when used in addition to highquality SRP has been shown to be effective in the treatment of periodontitis. Our literature researches revealed that the outcome of the studies about the effect of combined SRP+ doxcycline therapy in the glycemic control and on the alveolar bone loss of diabetic patients with periodontitis are controversial. Further studies are needed to enhance our understanding of the role of combined therapy (SRP+Doxcycline) in diabetic patients with periodontal disease.

Researches about the effects of combined therapy (BPs+LDD) in diabetics with periodontitis claimed that combined therapy did not affect the alveolar bone levels. Since there are limited numbers of research about the combined therapy (BPs+LDD) in diabetics with periodontitis, these findings should be verified by clinical human trials before BPs and/or doxycycline therapy are used in dental practice. In 
brief, there is insufficient evidence to suggest the integration of these drugs in the treatment of diabetics with periodontal disease.

\section{REFERENCES}

1.Listgarten MA. Pathogenesis of periodontitis. J Clin Periodontol 1986;13:418-30.

2.Çanakçı CF, Doğan GE. Role of nitric oxide in inflammatory periodontal diseases: a review. J Dent Fac Atatürk Uni 2014; 9:74-84.

3.Mealey $\mathrm{BL}$, Oates TW. Diabetes mellitus and periodontal diseases. J Periodontol 2006;77:1289303.

4.Saito T, Shimazaki Y, Kiyohara Y, Kato I, Kubo M, Iida $M$, Koga $T$. The severity of periodontal disease is associated with the development of glucose intolerance in non-diabetics: the Hisayama study. J Dent Res 2004;83:485-90.

5.Loe H. Periodontal disease. The sixth complication of diabetes mellitus. Diabetes Care 1993;16:329-334.

6.Campus G, Salem A, Uzzau S, Baldoni E, Tonolo G. Diabetes and periodontal disease: a case-control study. J Periodontol 2005;76:418-25.

7.Ozdemir SP, Kurtis B, Tuter G, Bozkurt Ş, Gültekin SE, Sengüven B, Watanabe K, Aydın S. Effects of low-dose doxycycline and bisphosphonate clodronate on alveolar bone loss and gingival levels of matrix metalloproteinase- 9 and interleukin1beta in rats with diabetes: a histomorphometric and immunohistochemical study. J Periodontol 2012;83:1172-82.

8.Duarte PM, Neto JB, Casati MZ, Sallum EA, Nociti FH, Jr. Diabetes modulates gene expression in the gingival tissues of patients with chronic periodontitis. Oral Dis 2007;13:594-9.

9.Llavaneras A, Ramamurthy NS, Heikkila $P$, Teronen O, Salo T, Rifkin BR, Ryan ME, Golub LM, Sorsa T. A combination of a chemically modified doxycycline and a bisphosphonate synergistically inhibits endotoxin-induced periodontal breakdown in rats. J Periodontol 2001;72:1069-1077.

10.Sharma A, Pradeep AR. Clinical efficacy of $1 \%$ alendronate gel as a local drug delivery system in the treatment of chronic periodontitis: a randomized, controlled clinical trial. J Periodontol 2012;83:11-8.

11.O'Doherty DP, Bickerstaff DR, McCloskey EV, Hamdy NA, Beneton MN, Harris S, Mian M, Kanis
JA. Treatment of Paget's disease of bone with aminohydroxybutylidene bisphosphonate. J Bone Miner Res 1990;5:483-91.

12.Watts NB, Harris ST, Genant HK, Wasnich RD, Miller PD, Jackson RD, Licata AA, Ross P, Woodson GC 3rd, Yanover MJ. Intermittent cyclical etidronate treatment of postmenopausal osteoporosis. N Engl J Med 1990;323:73-9.

13.Pradeep AR, Raghavendra NM, Sharma A, Patel SP, Raju A, Kathariya R, Rao NS, Naik SB. Association of serum and crevicular visfatin levels in periodontal health and disease with type 2 diabetes mellitus. J Periodontol 2012;83:629-34.

14.Buduneli E, Vardar-Sengul S, Buduneli N, Atilla G, Wahlgren J, Sorsa T. Matrix metalloproteinases, tissue inhibitor of matrix metalloproteinase-1, and laminin-5 gamma2 chain immunolocalization in gingival tissue of endotoxin-induced periodontitis in rats: effects of low-dose doxycycline and alendronate. J Periodontol 2007;78:127-34.

15.Yagan A, Kesim S, Liman N. Effect of low-dose doxycycline on serum oxidative status, gingival antioxidant levels, and alveolar bone loss in experimental periodontitis in rats. J Periodontol 2014;85:478-89.

16.Sarin J, DeRossi SS, Akintoye SO. Updates on bisphosphonates and potential pathobiology of bisphosphonate-induced jaw osteonecrosis. Oral Dis 2008; 14:277-85.

17. Hewitt C, Farah CS. Bisphosphonate-related osteonecrosis of the jaws: a comprehensive review. J Oral Pathol Med 2007;36:319-28.

18.Tenenbaum HC, Shelemay A, Girard B, Zohar R, Fritz PC. Bisphosphonates and periodontics: potential applications for regulation of bone mass in the periodontium and other therapeutic/ diagnostic uses. J Periodontol 2002; 73: 813-22.

19.Rodan GA, Fleisch HA. Bisphosphonates: mechanisms of action. J Clin Invest 1996;97:26926.

20.Mariotti A. Bisphosphonates and osteonecrosis of the jaws. J Dent Educ 2008;72:919-929.

21.Russell RG. Bisphosphonates: the first 40 years. Bone 2011;49:2-19.

22. Maruotti N, Corrado A, Neve A, Cantatore FP. Bisphosphonates: effects on osteoblast. Eur J Clin Pharmacol 2012;68:1013-8. 
23. Fleisch $\mathrm{H}$. Bisphosphonates in osteoporosis. Eur Spine J 2003;Supplement 12 2:S142-6.

24.Goya JA, Paez HA, Mandalunis PM. Effect of topical administration of monosodium olpadronate on experimental periodontitis in rats. J Periodontol 2006;77:1-6.

25.Rocha ML, Malacara JM, Sanchez-Marin FJ, Vazquez de la Torre $\mathrm{CJ}$, Fajardo ME. Effect of alendronate on periodontal disease in postmenopausal women: a randomized placebo-controlled trial. J Periodontol 2004;75:1579-85.

26.Lane N, Armitage GC, Loomer P, Hsieh S, Majumdar S, Wang HY, Jeffcoat $M$, Munoz T. Bisphosphonate therapy improves the outcome of conventional periodontal treatment: results of a 12-month, randomized, placebo-controlled study. J Periodontol 2005;76:1113-22.

27.Yamashita J, McCauley LK, Van Poznak C. Updates on osteonecrosis of the jaw. Curr Opin Support Palliat Care 2010;4:200-6.

28.Skoglund B, Holmertz J, Aspenberg P. Systemic and local ibandronate enhance screw fixation. J Orthop Res 2004;22:1108-13.

29.Peter B, Ramaniraka N, Rakotomanana LR, Zambelli PY, Pioletti DP. Peri-implant bone remodeling after total hip replacement combined with systemic alendronate treatment: a finite element analysis. Comput Methods Biomech Biomed Engin 2004;7:73-8.

30.Adachi $H$, Igarashi K, Mitani $H$, Shinoda H. Effects of topical administration of a bisphosphonate (risedronate) on orthodontic tooth movements in rats. J Dent Res 1994;73:1478-86.

31.Muhlemann HR, Bowles D, Schait A, Bernimoulin JP. Effect of diphosphonate on human supragingival calculus. Helv Odontol Acta 1970;14:31-3.

32.Jeffcoat MK, Kaplan ML, Goldhaber P. Predicting alveolar bone loss in beagles using bone-seeking radiopharmaceutical uptake. J Dent Res 1980;59:844-8.

33. Nicolay OF, Heeley JD, Jeffcoat MK, Jones AG. Autoradiographic localization of technetium-99 methylene diphosphonate in growth sites of young mice. Int J Rad Appl Instrum B 1988;15:157-63.

34.Jeffcoat MK, Williams RC, Kaplan ML, Goldhaber P. Nuclear medicine techniques for the detection of active alveolar bone loss. Adv Dent Res 1987;1:804.
35.Graziani F, Cei S, Guerrero A, La Ferla F, Vano M, Tonetti M, Gabriele M. Lack of short-term adjunctive effect of systemic neridronate in nonsurgical periodontal therapy of advanced generalized chronic periodontitis: an open labelrandomized clinical trial. J Clin Periodontol 2009;36:419-27.

36. Rocha M, Nava LE, Vazquez de la Torre C, Sanchez-Marin F, Garay-Sevilla ME, Malacara JM. Clinical and radiological improvement of periodontal disease in patients with type 2 diabetes mellitus treated with alendronate: a randomized, placebo-controlled trial. J Periodontol 2001;72:204-9.

37.Jeffcoat MK, Cizza G, Shih WJ, Genco R, Lombardi A. Efficacy of bisphosphonates for the control of alveolar bone loss in periodontitis. J Int Acad Periodontol 2007;9:70-6.

38.El-Shinnawi UM, El-Tantawy SI. The effect of alendronate sodium on alveolar bone loss in periodontitis (clinical trial). J Int Acad Periodontol 2003;5:5-10.

39. Menezes AM, Rocha FA, Chaves HV, Carvalho CB, Ribeiro RA, Brito GA. Effect of sodium alendronate on alveolar bone resorption in experimental periodontitis in rats. J Periodontol 2005;76:1901-9.

40.Reddy MS, Weatherford TW, 3rd, Smith CA, West $B D$, Jeffcoat MK, Jacks TM. Alendronate treatment of naturally-occurring periodontitis in beagle dogs. J Periodontol 1995;66:211-7.

41.de Almeida JM, Ervolino E, Bonfietti LH, Novaes VC, Theodoro LH, Fernandes LA, Martins TM, Faleiros PL, Garcia VG. Adjuvant Therapy With Sodium Alendronate for the Treatment of Experimental Periodontitis in Rats. J Periodontol 2015:1-18.

42.Goes P, Melo IM, Dutra CS, Lima AP, Lima V. Effect of alendronate on bone-specific alkaline phosphatase on periodontal bone loss in rats. Arch Oral Biol 2012;57:1537-44.

43.Sharma A, Pradeep AR. Clinical efficacy of $1 \%$ alendronate gel in adjunct to mechanotherapy in the treatment of aggressive periodontitis: a randomized controlled clinical trial. J Periodontol 2012;83:19-26.

44.Alencar VB, Bezerra MM, Lima V, Abreu AL, Brito GA, Rocha FA, Ribeiro RA. Disodium chlodronate prevents bone resorption in experimental periodontitis in rats. ] Periodontol 2002;73:251-6. 
45. Mitsuta T, Horiuchi $H$, Shinoda $H$. Effects of topical administration of clodronate on alveolar bone resorption in rats with experimental periodontitis. J Periodontol 2002;73:479-86.

46.Shibutani T, Inuduka A, Horiki I, Luan Q, Iwayama Y. Bisphosphonate inhibits alveolar bone resorption in experimentally-induced peri-implantitis in dogs. Clin Oral Implants Res 2001;12:109-14.

47.Takaishi Y, Ikeo T, Miki T, Nishizawa Y, Morii H. Suppression of alveolar bone resorption by etidronate treatment for periodontal disease: 4- to 5-year follow-up of four patients. J Int Med Res 2003;31:575-84.

48.Takaishi Y, Miki T, Nishizawa Y, Morii H. Clinical effect of etidronate on alveolar pyorrhoea associated with chronic marginal periodontitis: report of four cases. J Int Med Res 2001;29:35565.

49.Cetinkaya BO, Keles GC, Ayas B, Gurgor P. Effects of risedronate on alveolar bone loss and angiogenesis: a stereologic study in rats. J Periodontol 2008;79:1950-1961.

50.Shoji K, Horiuchi $H$, Shinoda $H$. Inhibitory effects of a bisphosphonate (risedronate) on experimental periodontitis in rats. J Periodontal Res 1995;30:277-84.

51.Furlaneto FA, Nunes NL, Oliveira Filho IL, Frota NP, Yamamoto KO, Lisboa MR, Ervolino E, Taba M Jr, Rêgo RO, Messora MR. Effects of locally administered tiludronic acid on experimental periodontitis in rats. J Periodontol 2014;85:1291301.

52.Weinreb M, Quartuccio H, Seedor JG, Aufdemorte TB, Brunsvold M, Chaves E, Kornman KS, Rodan GA. Histomorphometrical analysis of the effects of the bisphosphonate alendronate on bone loss caused by experimental periodontitis in monkeys. J Periodontal Res 1994;29:35-40.

53.Yamaguchi K, Motegi K, Iwakura Y, Endo Y. Involvement of interleukin-1 in the inflammatory actions of aminobisphosphonates in mice. $\mathrm{Br}$ J Pharmacol 2000;130:1646-54.

54.Adami S, Bhalla AK, Dorizzi R, Montesanti F, Rosini $S$, Salvagno G, Lo Cascio V. The acute-phase response after bisphosphonate administration. Calcif Tissue Int 1987;41:326-31.

55. Mealey B. Diabetes and periodontal diseases. J Periodontol 1999;70:935-49.
56. Hill PA. Bone remodelling. $\mathrm{Br} \mathrm{J}$ Orthod 1998;25:101-7.

57.Carnevale V, Romagnoli E, D'Erasmo E. Skeletal involvement in patients with diabetes mellitus. Diabetes Metab Res Rev 2004;20:196-204.

58. Kumeda Y. Bone metabolic abnormality in diabetes: especially about osteoblast dysfunction. Clin Calcium 2006;16:1277-85.

59.Wu YY, Xiao E, Graves DT. Diabetes mellitus related bone metabolism and periodontal disease. Int J Oral Sci 2015;7:63-72.

60.Toulis KA, Nirantharakumar K, Ryan R, Marshall T, Hemming $K$. Bisphosphonates and glucose homeostasis: a population-based, retrospective cohort study. J Clin Endocrinol Metab 2015;100:1933-40.

61.Buduneli E, Buduneli N, Vardar-Sengul S, Kardeşler L, Atilla G, Lappin D, Kinane DF. Systemic low-dose doxycycline and alendronate administration and serum interleukin-1beta, osteocalcin, and Creactive protein levels in rats. J Periodontol 2005;76:1927-33.

62.Shi F, Yu S, Xu L. Analysis of serum osteocalcin of patients with periodontitis. Zhonghua Kou Qiang Yi Xue Za Zhi 1996;31:300-2.

63.Lee NK, Sowa $H$, Hinoi E, Ferron $M$, Ahn JD, Confavreux C, Dacquin R, Mee PJ, McKee MD, Jung DY, Zhang Z, Kim JK, Mauvais-Jarvis F, Ducy P, Karsenty G. Endocrine regulation of energy metabolism by the skeleton. Cell 2007;130:456-69.

64.Chan DC, Yang RS, Ho CH, Tsai YS, Wang JJ, Tsai $\mathrm{KT}$. The use of alendronate is associated with a decreased incidence of type 2 diabetes mellitus--a population-based cohort study in Taiwan. PLoS One 2015;10:e0123279.

65.Schafer AL, Sellmeyer DE, Schwartz AV, Rosen CJ, Vittinghoff E, Palermo L, Bilezikian JP, Shoback DM, Black DM. Change in undercarboxylated osteocalcin is associated with changes in body weight, fat mass, and adiponectin: parathyroid hormone (1-84) or alendronate therapy in postmenopausal women with osteoporosis (the PaTH study). J Clin Endocrinol Metab 2011;96:E1982-9.

66.Ferron $M$, Wei J, Yoshizawa T, Del Fattore A, DePinho RA, Teti A, Ducy $P$, Karsenty G. Insulin signaling in osteoblasts integrates bone remodeling and energy metabolism. Cell 2010;142:296-308. 
67.Schwartz AV, Schafer AL, Grey A, Vittinghoff $E$, Palermo L, Lui LY, Wallace RB, Cummings SR, Black DM, Bauer DC, Reid IR. Effects of antiresorptive therapies on glucose metabolism: results from the FIT, HORIZON-PFT, and FREEDOM trials. J Bone Miner Res 2013;28:134854.

68.Pittas AG, Harris SS, Eliades M, Stark P, DawsonHughes B. Association between serum osteocalcin and markers of metabolic phenotype. J Clin Endocrinol Metab 2009;94:827-32.

69.Shea MK, Gundberg CM, Meigs JB, Dallal GE, Saltzman E, Yoshida M, Jacques PF, Booth SL. Gamma-carboxylation of osteocalcin and insulin resistance in older men and women. Am J Clin Nutr 2009;90:1230-5.

70.Ngarmukos C, Chailurkit LO, Chanprasertyothin S, Hengprasith B, Sritara P, Ongphiphadhanakul B. A reduced serum level of total osteocalcin in men predicts the development of diabetes in a longterm follow-up cohort. Clin Endocrinol (Oxf) 2012;77:42-6.

71.Motyl KJ, McCabe LR, Schwartz AV. Bone and glucose metabolism: a two-way street. Arch Biochem Biophys 2010;503:2-10.

72.Pradeep AR, Sharma A, Rao NS, Bajaj P, Naik SB, Kumari M. Local drug delivery of alendronate gel for the treatment of patients with chronic periodontitis with diabetes mellitus: a doublemasked controlled clinical trial. J Periodontol 2012;83:1322-8.

73. Watts NB, Marciani RD. Osteonecrosis of the jaw. South Med J 2008;101:160-5.

74.Marx RE. Pamidronate (Aredia) and zoledronate (Zometa) induced avascular necrosis of the jaws: a growing epidemic. J Oral Maxillofac Surg 2003;61:1115-7.

75.Ruggiero SL, Woo SB. Biophosphonate-related osteonecrosis of the jaws. Dent Clin North Am 2008;52:111-128, ix.

76.Ruggiero SL, Dodson TB, Assael LA, Landesberg R, Marx RE, Mehrotra B. American Association of Oral and Maxillofacial Surgeons position paper on bisphosphonate-related osteonecrosis of the jaws-2009 update. J Oral Maxillofac Surg 2009;67:2-12.

77.Manfredi M, Merigo E, Guidotti R, Meleti M, Vescovi $P$. Bisphosphonate-related osteonecrosis of the jaws: a case series of 25 patients affected by osteoporosis. Int J Oral Maxillofac Surg
2011;40:277-84.

78.Aghaloo TL, Kang B, Sung EC, Shoff M, Ronconi M, Gotcher JE, Bezouglaia O, Dry SM, Tetradis S. Periodontal disease and bisphosphonates induce osteonecrosis of the jaws in the rat. J Bone Miner Res 2011;26:1871-82.

79.Demerjian N, Bolla G, Spreux A. Severe oral ulcerations induced by alendronate. Clin Rheumatol 1999;18:349-50.

80.Gonzalez-Moles MA, Bagan-Sebastian JV. Alendronate-related oral mucosa ulcerations. J Oral Pathol Med 2000;29:514-8.

81.Anavi-Lev K, Anavi Y, Chaushu G, Alon DM, Gal G, Kaplan I. Bisphosphonate related osteonecrosis of the jaws: clinico-pathological investigation and histomorphometric analysis. Oral Surg Oral Med Oral Pathol Oral Radiol 2013;115:660-6.

82.Ficarra G, Beninati $F$, Rubino I, Vannucchi A, Longo G, Tonelli P, Pini Prato G. Osteonecrosis of the jaws in periodontal patients with a history of bisphosphonates treatment. J Clin Periodontol 2005;32:1123-8.

83.Saussez S, Javadian R, Hupin C, Magremanne M, Chantrain G, Loeb I, Decaestecker C. Bisphosphonate-related osteonecrosis of the jaw and its associated risk factors: a Belgian case series. Laryngoscope 2009;119:323-9.

84.Marx RE, Cillo JE, Jr., Ulloa JJ. Oral bisphosphonate-induced osteonecrosis: risk factors, prediction of risk using serum CTX testing, prevention, and treatment. J Oral Maxillofac Surg 2007;65:2397-410.

85.Deng X, Tamai R, Endo Y, Kiyoura Y. Alendronate augments interleukin-1beta release from macrophages infected with periodontal pathogenic bacteria through activation of caspase-1. Toxicol Appl Pharmacol 2009;235:97-104.

86.Makkonen N, Salminen A, Rogers MJ, Frith JC, Urtti A, Azhayeva E, Mönkkönen J. Contrasting effects of alendronate and clodronate on RAW 264 macrophages: the role of a bisphosphonate metabolite. Eur J Pharm Sci 1999;8:109-18.

87.Tsao C, Darby I, Ebeling PR, Walsh K, O'BrienSimpson N, Reynolds E, Borromeo G. Oral health risk factors for bisphosphonate-associated jaw osteonecrosis. J Oral Maxillofac Surg 2013;71:1360-6.

88.Urade M. [Diabetes mellitus and bisphosphonaterelated osteonecrosis of the jaws]. Clin Calcium 
2009;19:1332-8.

89. Molcho S, Peer A, Berg T, Futerman B, Khamaisi M. Diabetes microvascular disease and the risk for bisphosphonate-related osteonecrosis of the jaw: a single center study. J Clin Endocrinol Metab 2013;98:E1807-12.

90.Berti-Couto SA, Vasconcelos AC, Iglesias JE, Figueiredo MA, Salum FG, Cherubini K. Diabetes mellitus and corticotherapy as risk factors for alendronate-related osteonecrosis of the jaws: a study in Wistar rats. Head Neck 2014;36:84-93.

91. Watters AL, Hansen HJ, Williams T, Chou JF, Riedel E, Halpern J, Tunick S, Bohle G, Huryn JM, Estilo $\mathrm{CL}$. Intravenous bisphosphonate-related osteonecrosis of the jaw: long-term follow-up of 109 patients. Oral Surg Oral Med Oral Pathol Oral Radiol 2013;115:192-200.

92.Barasch A, Cunha-Cruz J, Curro FA, Hujoel $P$, Sung $A H$, Vena $D$, Voinea-Griffin $A E$; CONDOR Collaborative Group, Beadnell S, Craig RG, DeRouen T, Desaranayake A, Gilbert A, Gilbert GH, Goldberg K, Hauley R, Hashimoto M, Holmes J, Latzke B, Leroux B, Lindblad A, Richman J, Safford $M$, Ship J, Thompson VP, Williams OD, Yin W. Risk factors for osteonecrosis of the jaws: a casecontrol study from the CONDOR dental PBRN. J Dent Res 2011;90:439-44.

93.Demmer RT, Holtfreter B, Desvarieux M, Jacobs DR Jr, Kerner W, Nauck M, Völzke H, Kocher T. The influence of type 1 and type 2 diabetes on periodontal disease progression: prospective results from the Study of Health in Pomerania (SHIP). Diabetes Care 2012;35:2036-42.

94.Khamaisi M, Regev E, Yarom N, Avni B, Leitersdorf E, Raz I, Elad S. Possible association between diabetes and bisphosphonate-related jaw osteonecrosis. J Clin Endocrinol Metab 2007;92:1172-5.

95.Gu Y, Lee HM, Sorsa T, Simon SR, Golub LM. Doxycycline [corrected] inhibits mononuclear cellmediated connective tissue breakdown. FEMS Immunol Med Microbiol 2010;58:218-25.

96.Kopman JA, Kim DM, Rahman SS, Arandia JA, Karimbux NY, Fiorellini JP. Modulating the effects of diabetes on osseointegration with aminoguanidine and doxycycline. J Periodontol 2005;76:614-20.

97.Alkan A, Erdem E, Gunhan O, Karasu C. Histomorphometric evaluation of the effect of doxycycline on the healing of bone defects in experimental diabetes mellitus: a pilot study. J Oral Maxillofac Surg 2002;60:898-904.

98.Gomes PS, Fernandes MH. Effect of therapeutic levels of doxycycline and minocycline in the proliferation and differentiation of human bone marrow osteoblastic cells. Arch Oral Biol 2007;52:251-9.

99.Golub LM, McNamara TF, Ryan ME, Kohut B, Blieden T, Payonk G, Sipos T, Baron HJ. Adjunctive treatment with subantimicrobial doses of doxycycline: effects on gingival fluid collagenase activity and attachment loss in adult periodontitis. J Clin Periodontol 2001;28:146-56.

100.Mavragani M, Brudvik P, Selvig KA. Orthodontically induced root and alveolar bone resorption: inhibitory effect of systemic doxycycline administration in rats. Eur J Orthod 2005;27:21525.

101.Sgolastra F, Petrucci A, Gatto R, Giannoni M, Monaco A. Long-term efficacy of subantimicrobialdose doxycycline as an adjunctive treatment to scaling and root planing: a systematic review and meta-analysis. J Periodontol 2011;82:1570-1581.

102.Tsalikis L, Sakellari D, Dagalis P, Boura P, Konstantinidis A. Effects of doxycycline on clinical, microbiological and immunological parameters in well-controlled diabetes type-2 patients with periodontal disease: a randomized, controlled clinical trial. J Clin Periodontol 2014;41:972-80.

103. Martorelli de Lima AF, Cury CC, Palioto DB, Duro AM, da Silva RC, Wolff LF. Therapy with adjunctive doxycycline local delivery in patients with type 1 diabetes mellitus and periodontitis. J Clin Periodontol 2004;31:648-3.

104.Preshaw PM, Hefti AF, Jepsen S, Etienne D, Walker C, Bradshaw MH. Subantimicrobial dose doxycycline as adjunctive treatment for periodontitis. A review. J Clin Periodontol 2004;31:697-707.

105.Tella E, Aldahlawi S, Eldeeb A, El Gazaerly H. The Effect of Systemic Delivery of Aminoguanidine versus Doxycycline on the Resorptive Phase of Alveolar Bone Following modified Widman Flap in Diabetic Rats: A Histopathological and Scanning Electron Microscope (SEM) study. Int J Health Sci (Qassim) 2014;8:275-85.

106.Agarwal A, Bhattacharya HS, Srikanth G, Singh A. Comparative evaluation of decalcified freeze dried 
bone allograft with and without local doxycycline in non-contained human periodontal infrabony defects. J Indian Soc Periodontol 2013;17:490-4.

107.Llambes F, Silvestre FJ, Hernandez-Mijares A, Guiha R, Caffesse R. Effect of non-surgical periodontal treatment with or without doxycycline on the periodontium of type 1 diabetic patients. J Clin Periodontol 2005;32:915-20.

108.Bettany JT, Peet NM, Wolowacz RG, Skerry TM, Grabowski PS. Tetracyclines induce apoptosis in osteoclasts. Bone 2000;27:75-80.

109. Holmes SG, Still K, Buttle DJ, Bishop NJ, Grabowski PS. Chemically modified tetracyclines act through multiple mechanisms directly on osteoclast precursors. Bone 2004;35:471-8.

110.Caton JG, Ciancio SG, Blieden TM, Bradshaw M, Crout RJ, Hefti AF, Massaro JM, Polson AM, Thomas J, Walker C. Treatment with subantimicrobial dose doxycycline improves the efficacy of scaling and root planing in patients with adult periodontitis. J Periodontol 2000;71:521-32.

111.Golub LM, Ramamurthy NS, Kaneko H, Sasaki T, Rifkin B, McNamara TF. Tetracycline administration prevents diabetes-induced osteopenia in the rat: initial observations. Res Commun Chem Pathol Pharmacol 1990;68:27-40.

112.Gu Y, Walker C, Ryan ME, Payne JB, Golub LM. Non-antibacterial tetracycline formulations: clinical applications in dentistry and medicine. J Oral Microbiol 2012;4.

113.Golub LM, Lee HM, Ryan ME, Giannobile WV, Payne J, Sorsa T. Tetracyclines inhibit connective tissue breakdown by multiple non-antimicrobial mechanisms. Adv Dent Res 1998;12:12-26.

114.Agarwal A, Gupta ND. Combination of bone allograft, barrier membrane and doxycycline in the treatment of infrabony periodontal defects: A comparative trial. Saudi Dent J 2015;27:155-60.

115.Walker C, Thomas J, Nango S, Lennon J, Wetzel J, Powala C. Long-term treatment with subantimicrobial dose doxycycline exerts no antibacterial effect on the subgingival microflora associated with adult periodontitis. J Periodontol 2000;71:1465-71.

116.Caton JG, Ciancio SG, Blieden TM, Bradshaw M, Crout RJ, Hefti AF, Massaro JM, Polson AM, Thomas J, Walker C. Subantimicrobial dose doxycycline as an adjunct to scaling and root planing: post-treatment effects. J Clin Periodontol
2001;28:782-9.

117.Shahabooei M, Razavi SM, Minaiyan M, Birang R, Behfarnia P, Yaghini J, Naghsh N, Ghalayani P, Hajisadeghi S. A histomorphometric study of the effect of doxycycline and erythromycin on bone formation in dental alveolar socket of rat. Adv Biomed Res 2015;4:71.

118.Ryan ME, Ramamurthy NS, Golub LM. Tetracyclines inhibit protein glycation in experimental diabetes. Adv Dent Res 1998;12:1528.

119. Ryan ME, Ramamurthy NS, Sorsa T, Golub LM. MMP-mediated events in diabetes. Ann N Y Acad Sci 1999;878:311-34.

120.Singh S, Kumar V, Kumar S, Subbappa A. The effect of periodontal therapy on the improvement of glycemic control in patients with type 2 diabetes mellitus: A randomized controlled clinical trial. Int J Diabetes Dev Ctries 2008;28:38-44.

121.Promsudthi A, Pimapansri S, Deerochanawong C, Kanchanavasita W. The effect of periodontal therapy on uncontrolled type 2 diabetes mellitus in older subjects. Oral Dis 2005;11:293-8.

122. Macedo Gde O, Novaes AB, Jr., Souza SL, Taba M, Jr., Palioto DB, Grisi MF. Additional effects of aPDT on nonsurgical periodontal treatment with doxycycline in type II diabetes: a randomized, controlled clinical trial. Lasers Med Sci 2014;29:881-6.

123.O'Connell PA, Taba M, Nomizo A, Foss Freitas MC, Suaid FA, Uyemura SA, Trevisan GL, Novaes AB, Souza SL, Palioto DB, Grisi MF. Effects of periodontal therapy on glycemic control and inflammatory markers. J Periodontol 2008;79:77483.

124.Grossi SG, Skrepcinski FB, DeCaro T, Robertson DC, Ho AW, Dunford RG, Genco RJ. Treatment of periodontal disease in diabetics reduces glycated hemoglobin. J Periodontol 1997;68:713-9.

125.Al-Zahrani MS, Bamshmous SO, Alhassani AA, AlSherbini MM. Short-term effects of photodynamic therapy on periodontal status and glycemic control of patients with diabetes. J Periodontol 2009;80:1568-73.

126.Llambes F, Silvestre FJ, Hernandez-Mijares A, Guiha R, Caffesse R. The effect of periodontal treatment on metabolic control of type 1 diabetes mellitus. Clin Oral Investig 2008;12:337-43. 
127.Deo V, Gupta S, Bhongade ML, Jaiswal R. Evaluation of subantimicrobial dose doxycycline as an adjunct to scaling and root planing in chronic periodontitis patients with diabetes: a randomized, placebo-controlled clinical trial. J Contemp Dent Pract 2010;11:9-16.

128.Engebretson SP, Hey-Hadavi J. Sub-antimicrobial doxycycline for periodontitis reduces hemoglobin A1c in subjects with type 2 diabetes: a pilot study. Pharmacol Res 2011;64:624-9.

129.Gilowski L, Kondzielnik P, Wiench R, Plocica I, Strojek K, Krzeminski TF. Efficacy of short-term adjunctive subantimicrobial dose doxycycline in diabetic patients--randomized study. Oral Dis 2012;18:763-70.

130.Kaneko H, Sasaki T, Ramamurthy NS, Golub LM. Tetracycline administration normalizes the structure and acid phosphatase activity of osteoclasts in streptozotocin-induced diabetic rats. Anat Rec 1990;227:427-36.

131.Sasaki T, Kaneko H, Ramamurthy NS, Golub LM. Tetracycline administration restores osteoblast structure and function during experimental diabetes. Anat Rec 1991;231:25-34.

132. Fowlkes JL, Nyman JS, Bunn RC, Cockrell GE, Wahl EC, Rettiganti MR, Lumpkin CK Jr, Thrailkill $\mathrm{KM}$. Effects of long-term doxycycline on bone quality and strength in diabetic male DBA/2J mice. Bone Rep 2015;1:16-9.

133.Yaffe A, Herman A, Bahar $H$, Binderman I. Combined local application of tetracycline and bisphosphonate reduces alveolar bone resorption in rats. J Periodontol 2003;74:1038-42.

134.Buduneli E, Vardar S, Buduneli N, Berdeli AH, Türkoğlu O, Başkesen A, Atilla G. Effects of combined systemic administration of low-dose doxycycline and alendronate on endotoxin-induced periodontitis in rats. J Periodontol 2004;75:151623.

\section{Yazışma Adresi}

Yrd. Doç. Dr. Şeyma Bozkurt Doğan

Ankara Yıldırım Beyazıt Üniversitesi

Diş Hekimliği Fakültesi

Periodontoloji Anabilim Dalı

Ankara/ Türkiye

Fax: $+9(0312) 3241505$

Telephone: +9(0312)3241555

E-mail: dtseyma@hotmail.com 